Bangladesh J. Bot. 48(2): 217-222, 2019 (June)

\title{
LAND SUITABILITY ANALYSIS BASED ON SOIL PROPERTIES AND GIS FOR IMPROVING RICE PRODUCTIVITY IN BIHAR, INDIA
}

\author{
Manibhushan, Anil Kumar Singh*, S Mondal and N Chandra \\ ICAR Research Complex for Eastern Region, Patna, Bihar, India
}

Keywords: Land suitability, Classification, Soil, Toposheet, Rice productivity

\begin{abstract}
This study was conducted for land classification and analysis of image for defining the land suitability for improving rice crop productivity. Several criteria were considered for the determination of land suitability for rice crop. IRS P6 LISS III image and digitized toposheet of Madhubani district were used for the study. Taking all the variables into accounts, a comprehensive block-wise land suitability map for rice crop of the district has been developed using multicriteria approach and GIS. It was found that $22 \%$ of the total rice growing area i.e. 72418 ha are highly suitable, 63\% (224512 ha) are moderately suitable, 15\% (50372 ha) are marginally suitable and around 1\% (3356 ha) is unsuitable for rice crop in Madhubani district. However, it is presumed that the suitability of the rice growing areas may increase or decrease depending on the changes in soil parameters, rainfall, water availability, and other associated factors .
\end{abstract}

\section{Introduction}

Reliable and timely information about agriculture is very necessary for a country where agriculture is the main activity of majority of the people. Madhubani is a district of Bihar state of India, where agriculture is the main activity of the majority people. Rice is the main crop in this region. Farmers grow rice using conventional methods. As a result the production of rice is usually lower than the potential harvest. Obviously, there is a room for increasing productivity if the farmers adopt scientific rice production technology.

Land suitability analysis for different crops is a prerequisite for the optimum utilization of available land resources for sustainable agricultural production (Perveen et al. 2007). Soil parameters, such as the status of $\mathrm{N}$ (nitrogen), $\mathrm{P}$ (phosphorus), $\mathrm{K}$ (potassium), $\mathrm{OC}$ (organic carbon), EC (electrical conductivity), $\mathrm{pH}$, and micronutrients such as $\mathrm{Cu}$ (copper), $\mathrm{Mn}$ (manganese), $\mathrm{Zn}$ (zinc) and $\mathrm{Fe}$ (iron) are taken into consideration for the creation of land suitability maps, because soil-land information is very useful for the proper agricultural land use planning (Dumanski et al. 1987). Thus, judicial soil testing of this area could be of essential use for determining the status of $\mathrm{N}, \mathrm{P}, \mathrm{K}, \mathrm{pH}, \mathrm{OC}, \mathrm{EC}$ and micronutrients. In Madhubani district, general farmers do not have in hand formation on land classification to select suitable ones for profitable rice production. Nonetheless, some areas of Madhubani district is flood affected and flood prone during summer. In this condition remote sensing (RS) and geographic information system (GIS) technology would offer an important tool for land use and land cover classification, and mapping of areas suitable for rice crop production

Remote sensing is a technique to acquire spatial information about an object on the earth without contact. Remotely sensed imagery can be used for number of applications viz. monitoring of land use and cover change over a period and land use planning, urban planning, agricultural planning, creation of maps considering different parameters, image classification for different land use and land covers, soil conditions, water resources and vegetation mapping, etc. Remote sensing

*Author for correspondence: <anil.icarpat@gmail.com>. 
image classification is a combined process of image processing and classification techniques. Image classification is a process of assigning pixels to a specific class or categories. Image classification is of two types i.e. supervised and unsupervised. In supervised method of classification, numbers of classes are defined prior to classification of images, whereas, in unsupervised classification classes are defined after the classification of images. GIS is a tool for geo-data analysis and appraisal of natural resources. It allows integrating data bases generated from different sources including remote sensing on a single platform and the data may be analyzed efficiently in a spatio-temporal domain. GIS is used to create maps. In this work, several maps were created for land suitable area for rice crop using GIS. The aim of this work was to create maps showing suitable area for rice (Oryza sativa) crop using the properties of soils, soil topography, availability of water resources, etc. through multicriteria evaluation (MCE) technique using GIS to enhance the rice production in Madhubani district. MCE approach was used in this study as because this technique may be used to find solutions in decision making problems characterized by multiple alternatives that may be evaluated taking different decision criteria into consideration (Jankowski et al. 2001). MCE is also an effective tool for multiple criteria decisionmaking issues (Malezewski 2006).

\section{Materials and Methods}

The study area considered for present research is Madhubani district of Bihar, India. This district is located at a longitude of $25^{\circ} 59^{\prime}$ to $26^{\circ} 39^{\prime}$ East and latitude of $85^{\circ} 43^{\prime}$ to $86^{\circ} 42^{\prime}$ North. It occupies a total area of $3501 \mathrm{~km}^{2}$. Total cultivable land area is 232724 hectare, cropped area is 218381 hectare and the area of barren land/ uncultivable land is 1456.5 hectare. Average annual rainfall is $1273.2 \mathrm{~mm}$ and cropping intensity is around $134.23 \%$ in this district. This district consists of 20 blocks (Table 1) and is surrounded to the north by a hill region of Nepal extending to the border of its parent district Darbhanga in the south, Sitamarhi in the west and Supaul in the east. The main rivers are Kamla, Kareh, Balan, Bhutahi, Koshi and Adhwara. The soil of the district is highly calcarious and contains mixture of clay and sand in varying proportions. However, the major part of this district contains clay soil and the proportion of sand in the soil is negligible. So, this type of soil can retain moisture and is best suited for rice/paddy cultivation. Agricultural area is mainly rainfed but tanks, wells and tubewells are also used for the irrigation. A considerable part of this district is flood prone. Area of permanent pasture is 1372.71 ha and the area of different trees coverage is 8835.9 hectares. Total wetland area in this district is 3730 ha which accounts $2.5 \%$ of the geographical area of the district. The fluctuation in open water spread area is around 5\%. Post monsoon exposed area is 2411 ha, which is decreased to 2280 ha in premonsoon season. Rice, wheat and sugarcane are the main crops, though maize and vegetables are also widely grown. Fish cultivation is done in the water-logged area, tanks and ponds.

Different soil samples were collected from all the blocks of Madhubani district for determining soil $\mathrm{pH}, \mathrm{N}, \mathrm{P}, \mathrm{K}, \mathrm{OC}, \mathrm{EC}$ and micronutrients such as $\mathrm{Cu}, \mathrm{Mn}, \mathrm{Zn}$ and $\mathrm{Fe}$ of the soils. Data related to the status of ground water availability, utilization in agriculture, balance of ground water, stage of ground water development, annual rainfall, number of dug well, tube well, canal irrigation were also collected from different sources. So, a database was created for the storage and management of the above data in a proper manner. Data were inserted, updated, modified and retrieved from this database as and when required.

IRS LISS III data of 14th November 2006 was used for the classification and mapping in this research. IRS P6 LISS III provides data in 4 spectral bands viz. red, green, near infra-red (NIR) and short wave infra-red (SWIR) with 23.5 meter spatial resolution and 24 days repeat cycle. The spatial resolution is suitable for $1: 50,000$ scale mapping. Remotely sensed data require field 
observation, i.e. "ground truth" for its conversion into meaningful information. So, ground truthing was done with the help of global positioning system (GPS). Georeferencing of satellite data was done with the help of Survey of India (SOI) toposheet. After georeferencing, the image was classified for different land use and land covers viz., water body, agricultural land, settlement area, wetland and vegetation using supervised method of classification. Land suitability map for rice crop was created using the digitized toposheet of Madhubani district taking multicriteria, viz. soil properties i.e. the status of $\mathrm{N}, \mathrm{P}, \mathrm{K}, \mathrm{pH}, \mathrm{OC}, \mathrm{EC}$ and micronutrients in the soil, soil texture, soil topography, ground water availability for irrigation and rainfall into consideration.

Table 1. Name of blocks of Madhubani district under study.

\begin{tabular}{ll}
\hline Sl. No. & Name of blocks \\
\hline 1. & Andaratharhi \\
2. & Babubarhi \\
3. & Basopatti \\
4. & Benipatti \\
5. & Bisfi \\
6. & Ghoghardiha \\
7. & Harlakhi \\
8. & Jainagar \\
9. & Jhanjharpur \\
10. & Khajauli \\
\hline
\end{tabular}

\begin{tabular}{ll}
\hline Sl. No. & Name of blocks \\
\hline 11 & Ladania \\
12 & Lakhnaur \\
13 & Laukaha \\
14 & Laukahi \\
15 & Madhepur \\
16 & Madhubani \\
17 & Madhawpur \\
18 & Pandaul \\
18 & Phulparas \\
20 & Rajnagar \\
\hline
\end{tabular}

\section{Results and Discussion}

Land use and land cover map has been created using IRS LISS III P6 image of Madhubani district. A database has been created for the storage and management of data related to soil texture, slope of soil, soil properties such as $\mathrm{N}, \mathrm{P}, \mathrm{K}, \mathrm{pH}, \mathrm{OC}, \mathrm{EC}$ and micronutrients $(\mathrm{Cu}, \mathrm{Mn}, \mathrm{Zn}, \mathrm{Fe})$, ground water availability and its utilization in agriculture, rainfall, etc. Land suitability map for rice crop has been created using digitized toposheet of Madhubani district in the category of highly suitable, marginally suitable, moderately suitable and unsuitable areas of rice crop. Multicriteria such as soil properties, ground water availability, rainfall, etc. have been taken into consideration for the creation of land suitability map for rice crop. The status of N, P, K, pH and OC are shown in Figs 1-3. pH value indicates that the soils of Madhubani district belongs to three

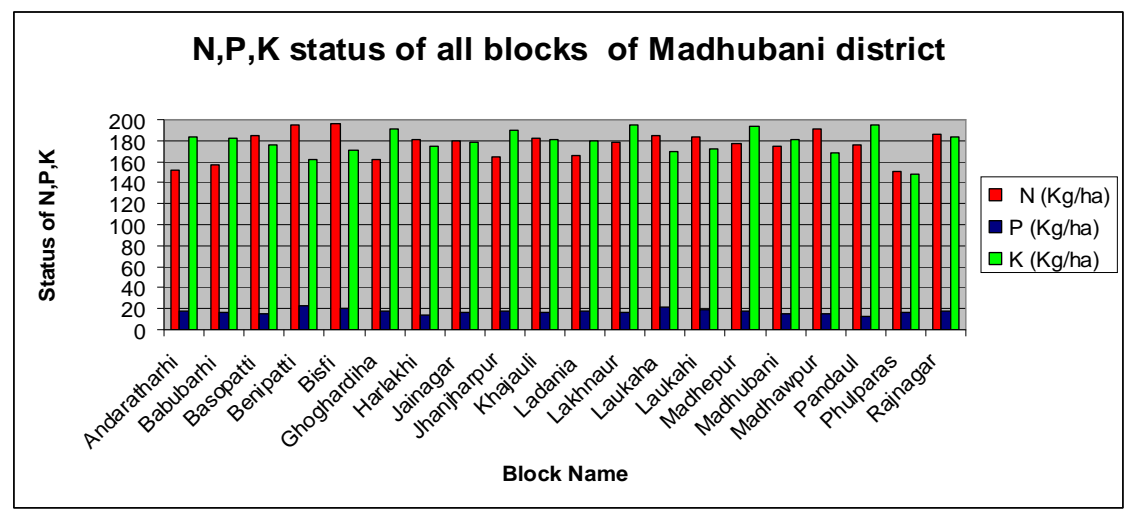

Fig. 1. Status of N, P and K (kg/ha) in 20 blocks of Madhubani district. 


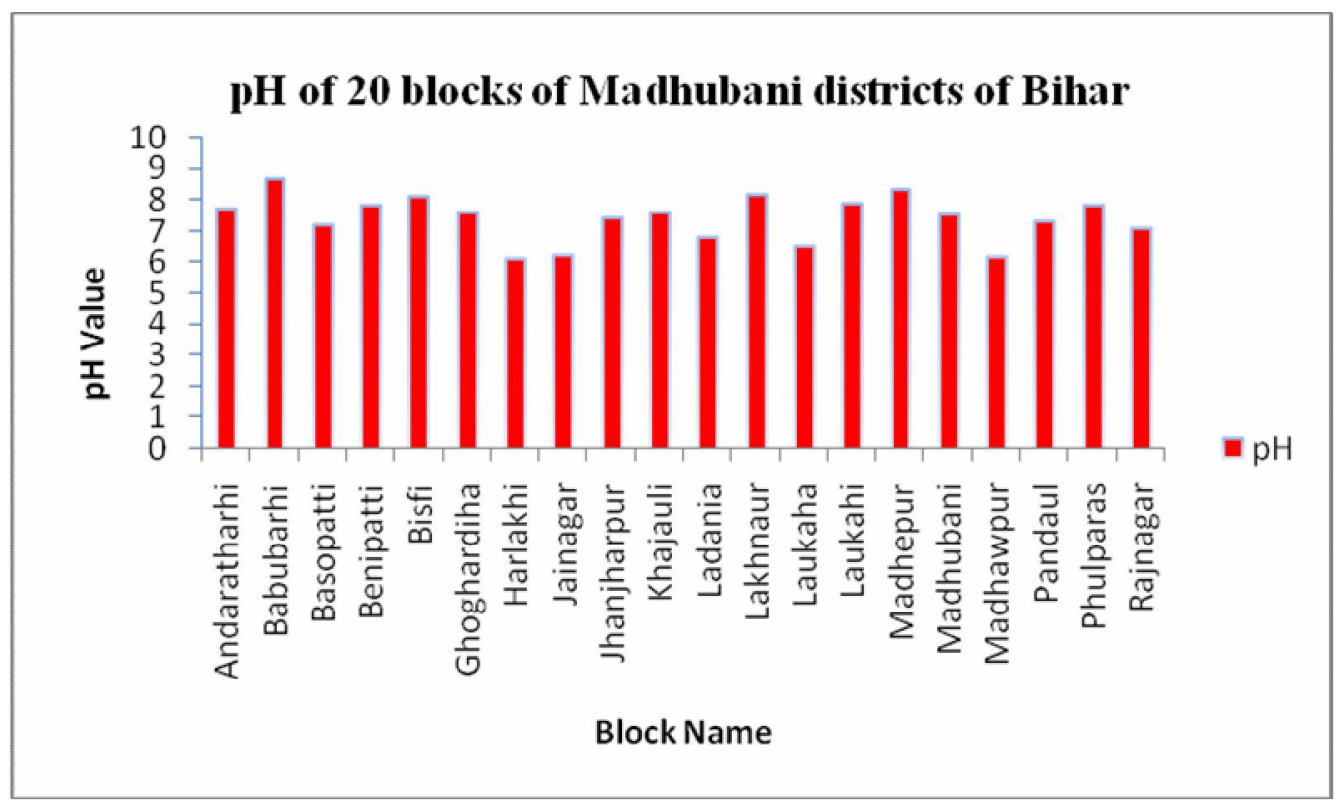

Fig. 2. Status of soil pH in soil of 20 blocks of Madhubani district.

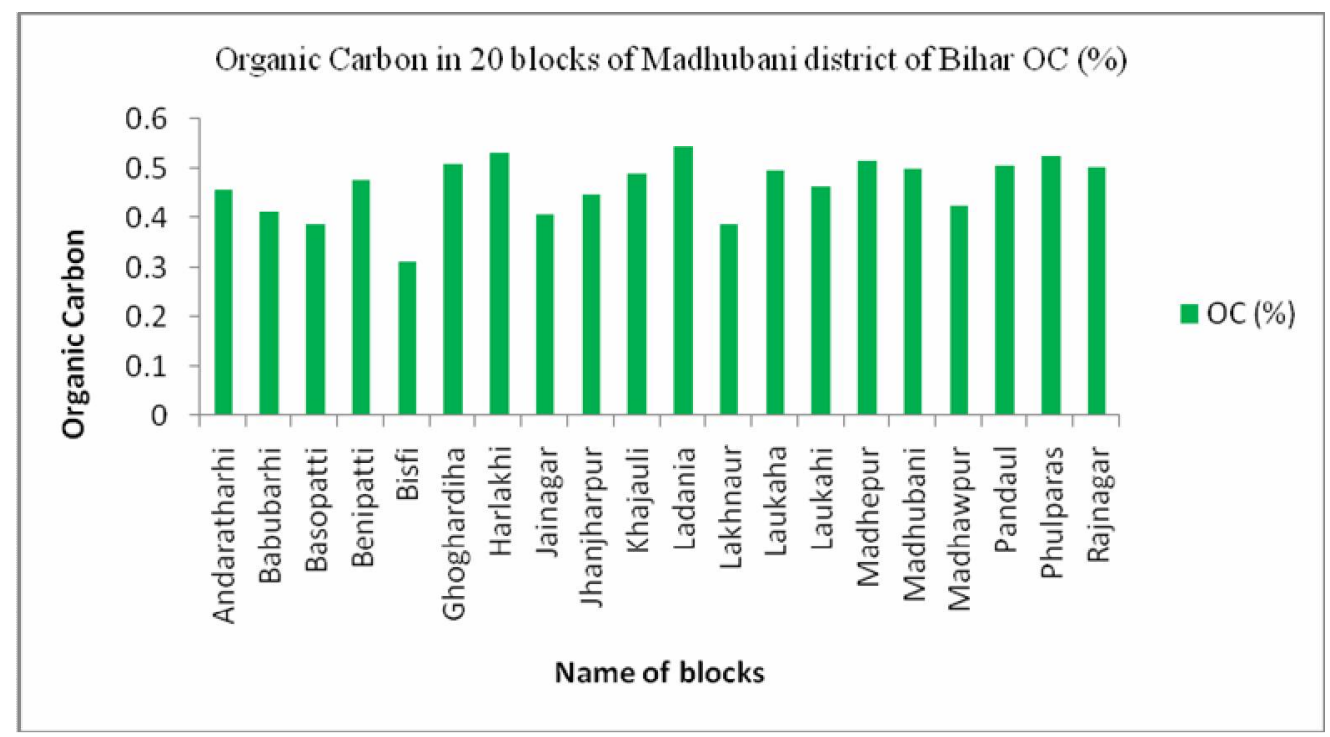

Fig. 3. Status of organic carbon in the soil of 20 blocks of Madhubani district.

categories that are neutral, acidic and alkaline. But the area of alkaline soil is more than the neutral and acidic soils. Block wise ground water availability (ha.m) of Madhubani district is shown in the Fig. 4. The land suitable areas for irrigated rice crop in this district are presented in Table 2 and Fig. 5 represents the map of different classes of suitable area for rice crop in the study area. 


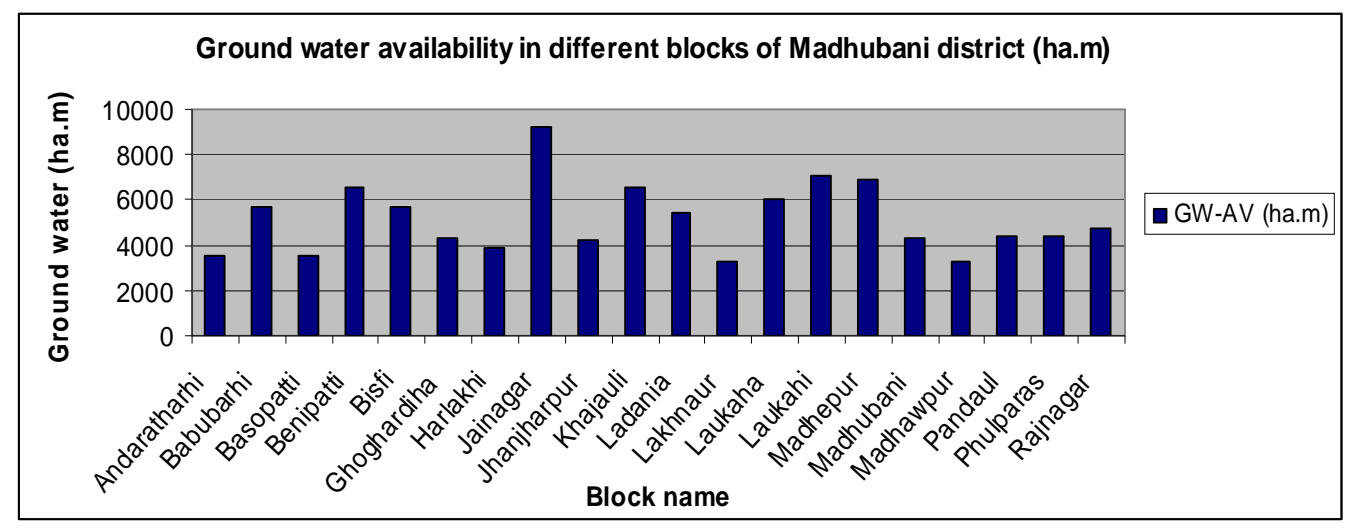

Fig. 4. Ground water availability in 20 blocks of Madhubani district.

Table 2. Land suitable area for rice crop in Madhubani district.

\begin{tabular}{lcc}
\hline $\begin{array}{l}\text { Land suitability for } \\
\text { rice crop }\end{array}$ & $\begin{array}{c}\text { Area in hectare } \\
\text { (ha) }\end{array}$ & $\begin{array}{c}\text { Percentage } \\
\text { area }\end{array}$ \\
\hline Highly suitable area & 72418 & 22 \\
Moderately suitable area & 224512 & 63 \\
Marginally suitable area & 50372 & 15 \\
Unsuitable & 3356 & 01 \\
\hline
\end{tabular}

\section{Land suitable area for rice (Madhubani)}

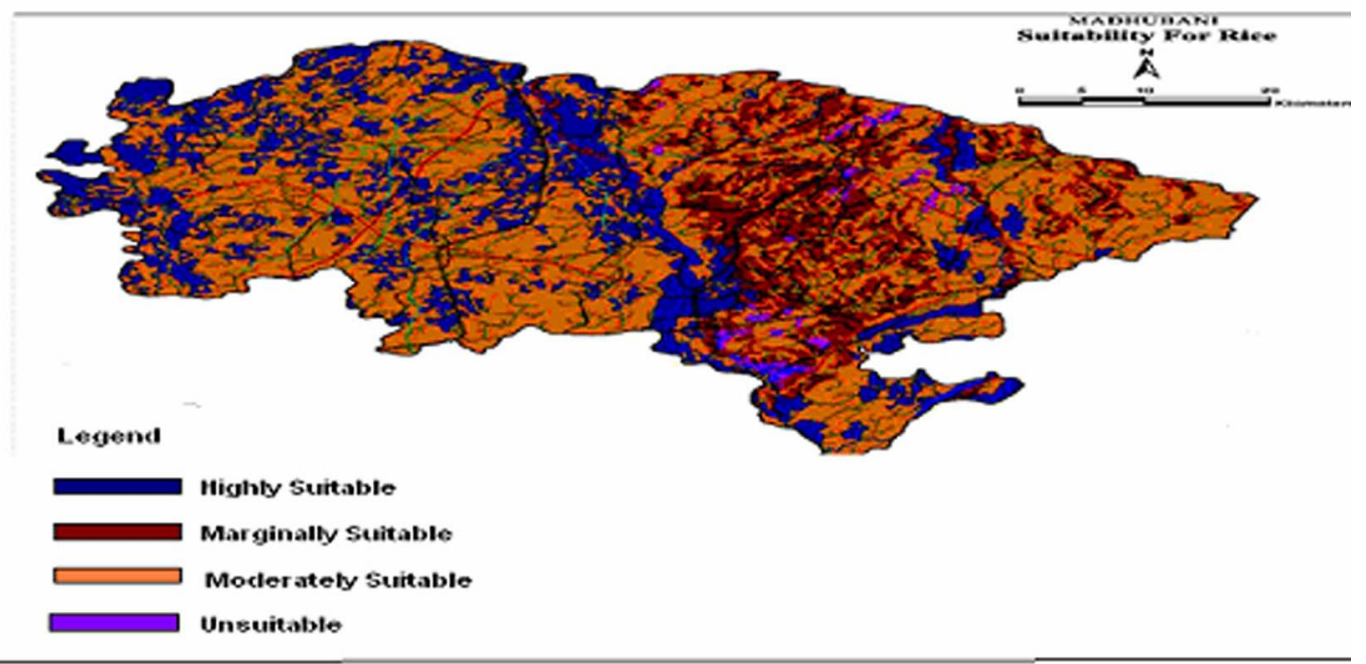

Fig. 5. Different classes of suitable area for rice in Madhubani district. 
The findings of the study revealed that in Madhubani district 22\% (72418 ha) of the total area is highly suitable, $63 \%$ (224512 ha) is moderately suitable, $15 \%$ (50372 ha) is marginally suitable and around 1\% (3356 ha) area is unsuitable for economic rice production. However, it is presumed that the area of each suitable class may increase or decrease depending on the changes in soil parameters, rainfall, water availability, and other associated factors.

\section{References}

Baniya N 2008. Land suitability evaluation using GIS for vegetable crops in Kathmandu valley, Nepal. Ph.D. thesis submitted to Humboldt University of Berlin.

Dumanski J, Phipps M and Huffman E 1987. A study of relationships between soil survey data and agricultural land use using information theory. Canadian Journal of Soil Science 67: 95-102.

JankowskiP, Andrienko N andAndrienko G 2001. Map-centered exploratory approach to multiple criteria spatial decision making. International Journal of Geographical Information Science 15(2):101-127.

Kanlaya T, Songkot D and Chalie N 2009. Integration of land evaluation and the analytical hierarchical process method for energy crops in Kanchanaburi, Thailand. Science Asia 53: 170-177.

Malezewski 2006. GIS-based multicriteria analysis: A survey of the literature. International Journal of Geographical Information Science 20: 703-726.

Mishra A and Sahu GC 1991. Sisal- the strongest vegetable fibre crops. Orissa Review, October.

Nayak DC, Sarkar D and Das K 2002. Forms and distribution of pedogenic iron, aluminium and manganese in somBenchmark soils of West Bengal. Journal of the Indian Society of Soil Science 50: 89-93.

Parveen F, Ryota N, Imtiaz U and Hssain KMD 2007. Crop land suitability analysis using multicriteria evaluation and GIS approach, $5^{\text {th }}$ International Symposium on Digital Earth. The University of California, Berkeley, USA. pp 1-8.

Pereira J MC and Duckstein L 1993. A multiple criteria decision- making approach to GIS based land suitability evaluation. International Journal of Geographical Information Science 7(5): 407-424.

Sehgal JL 1996. Pedology- concepts and Applications, Kalyani Publishers, Ludhiana.

Singh AK, Meena MK and Bharati RC 2011. Sulphur and Zinc Nutrient Management In Rice Lentil Cropping System. International Conference on "Life Science Research for Rural and Agricultural Development" 27-29 December 2011, CPRS Patna (Bihar). pp. 66-70. 